\title{
Store sprik
}

\section{Ei gransking av modulen "RLE i PEL» i grunnskulelaerarutdanninga}

\begin{abstract}
Av Kåre Fuglseth og Olav Kansgar Straum
Artikkelen presenterer resultat frå ei gransking av modulen religion, livssyn og etikk $i$ den nye, norske femårige grunnskulelorarutdanninga frå 2017. Modulen er fastlagt i forskrifta for utdanninga og er obligatorisk for alle studentar. Undersøkinga byggjer forst og fremst $p a$ materiale frå emne- og studieplanar, og viser store sprik mellom dei tolv loerarutdanningsinstitusjonane $i$ den lokale implementeringa av dei nasjonale retningslinene for modulen når det gjeld organisering og innhald. Det var djupe faglege og politiske stridar kring innforinga av faget, noko som kan forklare dei skilnadene vi har $i$ dag. Formuleringa i forskrifta om ein «integrert modul» har vore gjenstand for vide tolkingar. På bakgrunn av dei publiserte planane vurderer vi det slik at mange lorarstudentar ikkje vil fä den utdanninga som forskrifta legg opp til, og at nokre institusjonar kan seiast å bryte med henne.
\end{abstract}

Nøkkelord: Femårig grunnskulelærerutdanning, lærerutdanning, 1ærerprofesjon, RLE, religion, livssyn og etikk, PEL-faget, mangfaldskompetanse

KÅRe Fuglseth (f. 1959), professor i fagdidaktikk. Adresse: Fakultet for lararutdanning og kunst og kulturfag, Nord universitet. Postboks 1490, 8049 Bodø. E-post: kare.s.fuglseth@nord.no

Olav Kansgar Straum, 1966, forsteamanuensis i religionsdidaktikk. Adresse: Institutt for loerarutdanning og pedagogikk, Universitetet Tromsø, Norges arktiske universitet. Postboks 6050

Langnes, 9037 Tromsø. E-post: olav.k.straum@uit.no

\section{Den omdiskuterte RLE-Modulen}

I denne artikkelen presenterer vi resultat frå ei gransking av korleis den nye, obligatoriske undervisningsmodulen om religion, livssyn og etikk (RLE-modulen) er implementert i grunnskulelærarutdanningane (GLU). Modulen er kort sagt eit innføringskurs i sentrale RLE- og nokre andre danningstema for alle studentane i denne utdanninga. Han kom inn i utdanninga med innføringa av den femårige GLU-modellen i 2017 og er heimla i sjølve forskrifta (forskrift om rammeplan, KD 2016a og b). Modulen er lagt til det generelle profesjonsfaget pedagogikk og elevkunnskap (PEL). PEL-faget er det einaste fellesfaget i utdanninga, og alt fellesstoff med studiepoeng må leggjast dit. Implementeringsstudiar som dette kan studere korleis rammeplanen er realisert lokalt og om dette samsvarer med intensjonane for planen på nasjonalt og politisk nivå.

Vi har sett på korleis RLE-kunnskapsemna er implementerte slik dette kjem til uttrykk hovudsakleg i emneplanar på alle dei tolv grunnskulelærarutdannin-

Prismet - IKO-Forlaget 2020

Tilgjengelig på https://journals.uio.no/index.php/prismet. Publisert under CC BY-NC 4.o. Fagfellevurdert 
gane i Noreg, med unntak av den samisk-språklege utdanninga i Finnmark. Vi presenterer nedanfor status for implementeringa av modulen i studieåret 2019-20, medan det første kullet i denne utdanninga var om lag midtvegs.

Innføringa av modulen på nasjonalt nivå var omdiskutert. Usemjene var både politisk og fagleg motiverte (jf. nedanfor), og det kom tidleg til syne i diskusjonen om modulen ulike oppfatningar om kva nyutdanna lærarar nødvendigvis lyt kjenne til gjennom utdanninga. Undersøkinga vår prøver å sjå om desse usemjene har fătt utslag i dei lokale emneplanane for PEL-faget. Denne diskusjonen høyrer heime i ein større diskusjon om religion og livssyn i samfunnslivet og kva rolle staten og skulane skal ha i formidlinga av kunnskap om desse, særleg $\mathrm{i}$ høve til kristendomskunnskap. Han høyrer òg heime i ein større diskusjon om lærarutdanningane og forholdet mellom utdanning, skule, religion og livssyn i det fleirkulturelle samfunnet. Denne diskusjonen har vi kanskje berre sett starten på, og er lite trekt fram i studiar av grunnskulelærarutdanningane til no (jf. diskusjonen i Afdal og Bjordal 2019; Skagen 2016; Karlsen et al. 2017; Fosse og Hovdenak 2014). I Schjetne og Skrefsrud (red. 2018) «Å være lærer i en mangfoldig skole» gjekk fagfolk med bakgrunn frå RLE og frå PEL-faget i lærarutdanningane saman om å tematisere dette. Skrefsrud (2018) peikar i den samanhengen på korleis kunnskapsstoffet frå RLE kan verte integrert i PEL-faget om utdanninga skal vere mangfaldsorientert. Skeie (2018) løfter kor viktig innsikt i religions- og livssynsmangfaldet er, ikkje berre for lærarprofesjonen, men òg for allmenndanninga. Begge strekar under at mangfaldskompetansen sjølvsagt er meir enn innsikt i religionar og livssyn, men at dette stoffet ikkje kan utelatast. Intensjonen vår har ikkje vore å gå inn i debatten om innhaldet i lærarutdanninga, men vi brukar argumenta deira som stø for at undersøkinga er nødvendig. Ei slik gransking er ikkje berre grunngjeve i eit formalt, juridisk poeng om implementering av nasjonale vedtak, men peikar òg indirekte på alvoret i realitetane som ligg bak desse vedtaka.

Vi gjev først ei kort innføring i modulen slik han er nedfelt i lover og retningsliner for denne nye lærarutdanninga, for at det skal verte tydelegare kva for tema det dreier seg om. Deretter presenterer vi korleis vi har gått fram i studien med innsamlinga av kjeldematerialet og kva for variablar vi har brukt i vurderinga. Med dette utgangspunktet presenterer vi resultatet av granskinga, samanliknar dei ulike løysingane vi har funne og analyserer stoda for praktiseringa av modulen generelt. Vi vurderer så dette i lys av det rammeplanen og retningslinene seier. I tillegg vil vi løfte fram dei uttrykte intensjonane regjeringa Solberg la til grunn for forslaget i Stortinget og den fagpolitiske diskusjon om modulen i vurderinga av resultatet frå undersøkinga.

Som vi skal sjå, ligg dei lokale planane og arbeidet med modulen langt frå det som forskrifta legg opp til, med nokre unntak. Fleire institusjonar avviker frå 
formuleringane i retningslinene, og slik vi vurderer det, i nokre tilfelle er dei i strid med intensjonane bak ordninga, kanskje òg på kant med forskrifta. Ei sentral utfordring for dei som skulle lage lokale studie- og emneplanar i PEL-faget har vore å tolke uttrykket i rammeplanen om ein «integrert modul», og med det kva plass og innhald modulen skal ha i undervisningstilbodet. Dette er ei side ved organiseringa av den nye lærarutdanninga som vi vil prøve å avklare nedanfor.

\section{RLE-MODULEN I NASJONAL FORSKRIFT OG RETNINGSLINER} For å sikre realiseringa er modulen heimla i ei forskrift, noko som òg tyder at det er grenser for den sjølvråderetten institusjonane har når det gjeld undervisningstilbodet, kva det skal innehalde og korleis tilbodet er organisert. Forskrifta med rammeplanen (KD 2016a og b) seier at dette ikkje berre dreier seg om nokre kunnskapstema, formulerte som læringsutbyte i emneplanane og integrerte i PEL-faget. Ho seier òg at kunnskap om religion, livssyn og etikk skal utgjere ein modul tilsvarande 15 studiepoeng fordelt på fire år (KD 2016a, punkt 8):

For å styrke laererkompetansen $i$ et flerkulturelt og flerreligiøst samfunn, skal

kunnskap om religion, livssyn og etikk utgjøre en modul tilsvarende 15 studiepoeng

integrert i pedagogikk og elevkunnskapsfaget.

NOKUT (2016) laga retningsliner for akkreditering på bakgrunn av denne rammeplanen, og Universitets- og høgskulerådet (UHR) utarbeidde retningsliner for emneplanane i kvart utdanningsfag som gjev kompetanse til undervisning i ulike skulefag. NOKUT la fram krav til ei godkjenning eller akkreditering av studiet som mellom anna sa at utdanninga skulle vere ferdig planlagt med fullstendige studie- og emneplanar, tilstrekkelege formell fagkompetanse og ressursar før oppstartinga i 2017. I alle femårige masterutdanningar deler ein utdanningsløpet $i$ to syklusar. Syklus 1 er dei tre første åra og syklus 2 er dei to siste. Dei nasjonale retningslinene utarbeidde av UHR (Lærarutdanning) presenterer såleis òg læringsutbyta for RLE-modulen i to ulike syklusar (UHR 2017). Kvar institusjon vil på denne bakgrunnen måtte lage fleire emneplanar der modulen inngår på grunn av oppdelinga i syklusar, studieår og utdanningstypar (utdanning for undervisning $i$ klassestega 1-7 eller i 5-10).

I syklus 1 er dei sentrale kunnskapstemaa i modulen den norske skulen i lys av kristen tradisjon, sekularisering og pluralisme og kjennskap til sentrale religionar og livssyn i Noreg og deira rolle for elevane. ${ }^{1}$ Når det gjeld dugleikar er grunn-

$1 \ll$ «... har kunnskap om den norske skolen i lys av kristen tradisjon, sekularisering, pluralisme og fundamentalisme; kjenner til sentrale religioner og livssyn i Norge og deres betydning for elever» (retningsliner for GLU i UHR 2018a). Formuleringa om at studenten skal ha kunnskap om den norske skulen «i lys av ... fundamentalisme», er ikkje heilt klår. Sannsynlegvis ønskjer ein berre å poengtere at læraren veit kva fundamentalisme er i ulike religionar og livssyn---inkludert politiske ideologiar og kva ein skal gjere om ein møter det i skulen. Noko stort problem er dette neppe. 
gjeving, formidling og bruk av dokument om menneskerettane og barns rettar sentrale. I samband med generell kompetanse, dvs. overføringsverdi av emna til læraryrket generelt, trekkjer retningslinene fram arbeidet med didaktiske utfordringar og konsekvensar av det fleirkulturelle samfunnet og ein skule prega av mangfald. Mangfaldet vert sagt å vere både språkleg, kulturelt og religiøst. ${ }^{2}$ «Kultur» dekkjer vanlegvis både religion og språk, så denne bruken av ordet «kulturell» viser til kulturelle trekk utanom dei reint språklege og religiøse, dvs. om klede, soger, festar, veremåtar, skikkar, høgtider o.l. Retningslinene nemner òg heim-skulesamarbeidet og livssynsmangfaldet i denne samanhengen. Ordet «livssyn» inkluderer nok religion, men uttrykket bryt då med bruksmåten for ordet i læreplanen i KRLE-faget, som klart skil mellom religion og livssyn.

I syklus 2 er det berre eitt kunnskapstema: danning i eit pluralistisk samfunn. Denne kunnskapen skal vere «avansert», noko som til dømes kan tolkast slik at ein må løfte refleksjonen også ut over den praktiske kvardagen i skulen og studere prinsipp eller ytre tilhøve som påverkar danningsprosessen. Når det gjeld dugleikar, skal studentane kunne kritisk analysere og bruke verdigrunnlaget $\mathrm{i}$ skulen, og dei skal identifisere og drøfte profesjonsetiske spørsmål forankra i etisk teori. I samband med den generelle overføringsverdien av kunnskapsemna, seier retningslinene at studentane skal kunne identifisere og analysere dei utfordringane ein pluralistisk skule gjev i skulekvardagen og utnytte dei moglege handlingsvegane dette fører med seg. ${ }^{3}$

Trekt saman i essensielle formuleringar kan ein seie at modulen skal ta opp desse 11 kunnskapstema:

1 kristen tradisjon

2 sekularisering

3 pluralisme

4 fundamentalisme

5 sentrale religionar (inkludert kristendomen) og livssyn

6 menneskerettar og barns rettar

7 didaktiske konsekvensar av mangfald

8 samarbeidet heim-skule

9 danning i samfunnet

10 verdigrunnlaget (kristent og humanistisk) og

11 profesjonsetikk med grunnlagsetikk.

2 «... har kunnskap om og kan drøfte didaktiske konsekvenser, utfordringer og muligheter i en skole preget av språklig, kulturelt og religiøst mangfold» (UHR 2018a).

3 «... kan kritisk analysere og anvende skolens verdigrunnlag; kan identifisere og drøfte profesjonsetiske spørsmål forankret i etisk teori; kan identifisere og analysere utfordringer i skolehverdagen i en pluralistisk skole og utnytte muligheter den gir» (UHR 2018a). Ein «pluralistisk» skule er ei tvitydig formulering som ein kanskje burde ha unngått. Vanlegvis er «pluralisme» termen på ein relativistisk ideologi, medan «plural» er den deskriptive termen for mangfald. 
Demokrati og medborgarskap er ikkje nemnde, noko som det tematisk er naturleg å ta inn i eit slikt RLE-danningsemne, men dette er blant dei overordna temaa i grunnskulen og noko ein i lærarutdanninga skal dekkje gjennom alle studiefag, ikkje berre i PEL-faget. Nokre tema er særs generelle av natur, til dømes «profesjonsetikk», som kan dekkje alle sider av yrkesutøvinga, men på ein eller annan måte i denne samanhengen er dei alle særleg knytte til fleirkulturelle utfordringar og mangfaldskompetanse hjå lærarane. Formuleringane i retningslinene er relativt opne når det gjeld organisering, medan utvalet av kunnskapstemaa er meir konkret og avgrensa. Kristendomen vert som einaste religion trekt fram, så føremålsparagrafen for grunnskulen kan òg seiast å ha lagt føringar for debatten om innhaldet i denne lærarutdanninga. ${ }^{4}$

\section{EMNE- Og STUdiePlanAR SOM KJELDER I EIN IMPLEMENTERINGSSTUDIE}

Artikkelen er ein fokusert implementeringsstudie. Fokusert vil for det første seie at det dreier seg om implementeringa eller innføringa av éin del av rammeplanen, for det andre at vi berre har sett på implementeringa i den første fasen, og for det tredje at materialet først og fremst er tekstbasert. Metodologisk ligg studien innanfor kvalitativ innhaldsanalyse (jf. Mayring 2015). Dette er ei hermeneutisk tilnærming med tuft i kommunikasjonsteori. Tolking av juridisk forpliktande tekstar står sentralt, med dei særeigne problema autorative tekstar gjev, og dei kontekstuelle lesemåtane ein studie av implementeringa av slike tekstar krev. Rammeplanar er juridisk forpliktande og difor grunnleggjande i denne samanhengen. Opprettinga av RLE-modulen er ein del av rammeplanen for denne utdanninga og såleis eit sentralt styringsdokument for PEL-faget.

Det er ikkje enkelt å studere implementering av ei så stor omlegging av lærarutdanningane som vi fekk med den femårige modellen i 2017. Det er litt enklare å studere realiseringa av RLE-modulen i PEL-faget. Men å få eit fullstendig bilete berre av denne delen av GLU-en er òg krevjande utan inngåande studiar av den operative utdanninga gjennom brukarintervju, observasjonar og survey. Når dette av praktiske grunnar ikkje har late seg gjere, har vi avgrensa studien til det formelle nivået, og i første omgang studert publiserte emneplanar og studieplanar eller program. I nokon grad er dette supplert med semesterplanar, e-brev og telefonintervju med dei fagansvarlege, dvs. uformelle kjelder. Dette gjev totalt sett sjølvsagt berre indikasjonar på praksis. Mangel på bevis er ikkje bevis på mangel, men om vi finn manglar på det formelle nivået, er det sterke indikasjonar på manglande praksis. Det er lagt nasjonale føringar på innhaldsformuleringar i PEL-faget som

4 Opplæringslova par. 1.1. seier: «Opplæringa skal byggje på grunnleggjande verdiar i kristen og humanistisk arv og tradisjon, slik som respekt for menneskeverdet og naturen, på åndsfridom, nestekjærleik, tilgjeving, likeverd og solidaritet, verdiar som òg kjem til uttrykk i ulike religionar og livssyn og som er forankra i menneskerettane» jf. Grunnskolelova (1998). 
institusjonane må følgje. Det som absolutt gjeld, er det som står i dei to forskriftene (for GLU 1-7 og GLU 5-10). Slingringsmonnen er liten, så vi vil tolke avvik som vesentlege. Då dei første analysane vart fullførte og matrisene vart ferdig oppstilte, sende vi dei i tillegg på høyring til dei ansvarlege på kvar institusjon for å sikre oss at vi hadde oppfatta gjeldande emneplanar rett.

I studieåret 2019-20 var den nye grunnskulelærarutdanninga inne i det tredje driftsåret sitt, og det var no mogleg å studere korleis forskrifta var tolka og sett ut i livet på kvar institusjon for 1. -3. studieåret (syklus 1) i heile landet. I nokon mon var det òg mogleg å seie noko om syklus 2 på bakgrunn av planane for 4 . og 5 . studieår. Biletet av situasjonen vart likevel framleis noko uklårt fordi fleire institusjonar enno ikkje hadde utarbeidd alle emneplanane for syklus 2 (masternivået, 4. -5. studieår) slik NOKUT eigentleg hadde kravd. Det endelege biletet av korleis det har gått med heile modulen vil det sannsynlegvis ikkje vere mogleg å vite noko om før etter at det første kullet har gjennomført heile studiet i 2022.

Emneplanane for kvar institusjon er relativt enkelt tilgjengelege på Internett. Når det gjeld dei uformelle kjeldene, kontakta vi alle dei 12 institusjonane ved dei RLE-ansvarlege på e-post. Ofte peika desse på andre fagpersonar, anten studieleiar eller leiar for pedagogikk-miljøet (PEL) med ansvar for RLE-modulen. Dei 12 institusjonane er:

1 UiT Noregs arktiske universitet: Tromsø og Alta

2 Nord universitet: Bodø, Nesna og Levanger

3 NTNU Trondheim

4 Høgskulen på Vestlandet: Bergen, Sogndal og Stord

5 Universitetet i Sørøst-Norge: Tønsberg, Porsgrunn, Notodden og Drammen

6 Høgskulen i Innlandet

7 NLA-Høgskolen: Bergen og Oslo

8 Høgskulen i Volda

9 Universitetet i Stavanger

10 Universitetet i Agder

11 OsloMet, storbyuniversitet

12 Høgskulen i Østfold

Studie- og emneplanar frå desse tolv utdanningsinstitusjonane er vurderte ut frå variablar som vi meiner er relevante for ei gransking av implementeringa. Før presentasjonen av analysen vil vi difor presentere kva som er variablane i vurderinga. 


\section{Sentrale Variablar for VURDeringa}

Uttrykket «integrert modul» eller «en modul tilsvarende $15 \mathrm{p}$ integrert $\mathrm{i}$ pedagogikk- og elevkunnskapsfaget» i forskrifta (jf. KD 2016a og b) var gjenstand for debatt nasjonalt (jf. nedanfor). Korkje denne forskrifta med rammeplanen for utdanninga, rundskrivet med tolkingar av forskrifta («F-06-16» KD 2016c) eller dei nasjonale retningslinene frå UHR (2018 a og b) seier noko meir om korleis ein skal forstå ordet «modul» i denne samanhengen. Det som vert sagt, er at han skal vere «integrert» i PEL-faget, og at arbeidsmengda skal svare til 15 studiepoeng.

Vi meiner at det er rimeleg å tolke «integrert» slik at emna skal inngå i emneplanane for PEL-faget med læringsutbyteformuleringar, pensumlitteratur, arbeidsformer og vurderingsmåtar. Alternativet ville ha vore å ta modulen ut av emneplanane i PEL med eigen organisering og vurdering, noko rammeplanen altså ikkje legg opp til. Slik vi tolkar forskrifta, kan likevel ikkje integrasjonen vere total, for det skal vere ein «modul». Dette tyder at han må vere synleg eller konkret på eitt vis. Då må det vere ei organisert eining som inkluderer uttrykket «RLE» eller «religion, livssyn og etikk», t.d. «modulen RLE i PEL», og at «modulen» ikkje berre er kunnskapstema spreidde utover og under andre overskrifter i plandokumenta som «samarbeid heim-skule», «fleirkulturelt samfunn» eller «klasseleiing». Det bør gå fram kor i planen og kor mange studiepoeng RLE-temaa skal ha, slik at studentane veit kva dei går til. Ei slik tolking av modulen som «synleg og integrert» styrkjer seg i lys av den politiske presentasjonen av modulen i Stortinget (sjå nedanfor). Ein kan kanskje innvende at ordet modul i forskrifta er meint å vere vag og såleis skal kunne tolkast vidt. Men kvifor er ordet brukt i det heile teke i forskrift og retningsliner? Ei tolking av forskrifta i emneplanane der ordet modul er overflødig, er etter vår meining urimeleg og feil.

I utgangspunktet tenkjer vi òg at emneplanane ikkje kan late vere å ta med kvalifiserande forklaringar som «fleirreligiøst» og «religion og livssyn» når dei presenterer innhaldet, for då vil den nye tematiske retninga berre forsvinne. I læreplanane for grunnskulen er religion og livssyn definert som to ulike fenomen. I desse er «livssyn» organiserte, sekulære retningar, så begge nemningane (religion og livssyn) må vere med.

Ut frå denne tolkinga av forskrifta vil vi undersøkje om, og eventuelt kor dei 15 studiepoenga i modulen er fordelte på syklus eller år ved desse institusjonane. Om institusjonar ikkje kan gjere greie for kor læringsutbyteformuleringar tilsvarande 15 studiepoeng har teke vegen i emneplanane, ser vi på dette som ein situasjon der forskrifta ikkje er oppfylt. Vi har òg vore interesserte i om arbeidskrav og vurderingsformer knytte til RLE eksplisitt er formulerte i emneplanane i PEL. Då får vi eit blikk for kor forpliktande institusjonane ser på desse kunnskapsemna. Av same grunn har vi òg undersøkt om RLE-relevant pensum er med, tilsvarande 15 poeng, i tråd med dei 11 hovudtemaa presenterte ovanfor. Det finst ikkje formelle 
krav til storleiken på pensum i høgare utdanning, det varierer frå fag til fag og mellom utdanningstypane, men ein kan samanlikne utdanningar av same type og sjå om det er store skilnader. Gjennom e-post og telefonkontakt (dei uformelle kjeldene) har vi òg prøvd å danne oss eit bilete av den faglege bakgrunnen hjå førelesarane i RLE-emna eller dei som møter studentane i læringsøktene. Fagleg bakgrunn kan seie litt om kva for retning undervisninga tek.

Variablane som ligg til grunn for vurderinga er såleis:

1 Formell modulisering av 15p RLE fordelt på syklusar eller studieår

2 Arbeidskrav der RLE-emna eksplisitt inngår

3 Vurderingsformer i RLE-modulen

4 Pensum i RLE-emna

5 Den faglege bakgrunnen hjå førelesarane

6 Integrering av læringsutbyteformuleringar i emneplanane

\section{IMPLEMENTERINGA AV RLE-MODULEN: HOVUDRESULTAT}

Som det går fram av matrise 1, har berre fem (5) av dei 12 lærarutdanningsinstitusjonane ei formell implementering av RLE-modulen med 15 studiepoeng $\mathrm{i}$ PEL-faget. Dette gjeld OsloMet Storbyuniversitetet, Nord universitet, Universitetet i Sørøst-Norge, Høgskulen i Volda og Høgskolen i Østfold. Alle desse institusjonane har ei emneplanfesta fordeling av 15 studiepoeng innanfor syklus 1 og 2. Universitetet i Sørøst-Norge har berre presisert dette i programplanen for heile utdanninga, ikkje i emneplanen.

Matrise 1: Grad av formell mudulisering av 15p RLE i PEL-faget

\begin{tabular}{|l|l|}
\hline Institusjonar med formell modulisering & Institusjonar utan formell modulisering \\
\hline Oslo Met & Universitet i Tromsø \\
\hline Nord Universitet & Høgskolen i Innlandet \\
\hline Universitetet i Sørøst-Norge & Universitetet i Stavanger \\
\hline Høgskulen i Volda & NTNU \\
\hline Høgskolen i Østfold & Høgskulen på Vestlandet \\
\hline & Universitetet i Agder \\
\hline & NLA, Bergen \\
\hline
\end{tabular}

\section{Matrise 1}

\section{A. Institusjonar med formell modulisering av 15 studiepoeng med RLE i PEL}

Korleis RLE-modulen er implementert og integrert innanfor denne hovudgruppa, varierer likevel i stor grad. Nokre institusjonar har gjennomarbeidde emneplanar 
som eksplisitt knyter arbeidskrav og vurderingsformer opp mot RLE-modulen. Dette gjeld Nord universitet og delvis Høgskulen i Volda og Høgskolen i Østfold. Dei andre institusjonane i denne gruppa (OsloMet og Universitetet i SørøstNorge) har ikkje, eller har berre i liten grad, emneplanfesta desse parametrane. Den sistnemnde institusjonen har korkje presisert RLE-spesifikke arbeidskrav eller vurderingsformer i emneplanen. Dette oppfattar vi som ein vesentleg mangel, då intensjonen i forskrifta er å «... styrke lærerkompetansen i et flerkulturelt og flerreligiøst samfunn» (forskrifta, KD 2016a og b). Dette målet kan lett verte svekt i den faglege interessekonflikten mellom ulike miljø på ei slik utdanning med mange ulike basisfag når det ikkje er nedfelt i planane. Manglande presisering i emneplanane tyder sjølvsagt ikkje at dei RLE-faglege emna i praksis er fråverande når det kjem til arbeidskrav og vurderingsformer. Likevel kan ei slik manglande formell presisering skape årlege variasjonar, og resultatet vil mellom anna vere avhengig av den faglege interessa og kompetansen åt dei aktuelle fagpersonane som har ansvar for modulen år om anna. Men ei kartlegging av den faktiske og uoffisielle implementeringa ligg som sagt utanfor det vi har kunna gjere her i denne undersøkinga.

Berre Nord universitet og Høgskolen i Østfold har emneplanfesta vurderingsformer der RLE-emna må vere med. Alle dei andre institusjonane i denne første gruppa har late dette stå ope. Det er likevel fullt mogleg at desse andre institusjonane har ein uformell praksis der RLE-måla vert vurderte gjennom eksamen og liknande. Men i og med at dette ikkje er emneplanfesta, vil praksisen vere avhengig av det fagpersonalet som til kvar tid har ansvaret for emnet.

Når det gjeld pensumlitteratur offentleggjort via Internett, ser vi følgjande: Det er berre tre institusjonar i denne gruppa som har offentleggjort litteraturen via emneplanen på nett. Av disse er det to institusjonar som legg opp til eit pensum som svarer til ca. $80-100$ sider pr. studiepoeng. Dette er Nord universitet og Høgskulen i Volda (sistnemnde har berre pensum for syklus 1 fastlagt på dette tidspunktet). Slik vi tolkar pensumlitteraturen ved Høgskolen i Østfold, er det berre 575 sider som er RLE-relevante. Dermed ligg denne institusjonen på ein faktisk pensumnorm i underkant av 40 sider pr. studiepoeng (sjå matrise 2). Det er mogleg at dei som har vesentleg mindre lesestoff, kompenserer med andre typar tekstar som ikkje står i emneplanen. Vi oppfattar 40 sider i lesestoff pr. studiepoeng som særs lite om dette er det studentane skal lese, og at Nord universitet og Volda ligg om lag der kravet bør vere for å dekkje eit komplekst område som RLE tilstrekkeleg. Dei andre institusjonane i denne gruppa har ikkje offentleggjort pensum via emneplanane, og fleire av institusjonane har heller ikkje ferdigstilt pensum for syklus 2 . Vi har difor ikkje kunna vurdere det endelege omfanget av det RLE-faglege pensumet på desse institusjonane. 
Matrise 2: Korleis er 15p modulisert? Institusjonar med formell modulisering

\begin{tabular}{|c|c|c|c|c|c|}
\hline Institusjonar & $\begin{array}{l}\text { Talet på stud- } \\
\text { iepoeng fordelt } \\
\text { på syklus/år }\end{array}$ & $\begin{array}{l}\text { Arbeidskrav der RLE } \\
\text { eksplisitt inngår }\end{array}$ & $\begin{array}{l}\text { Vurderingsformer } \\
\text { i RLE-modulen }\end{array}$ & Pensum i RLE & $\begin{array}{l}\text { Den faglege } \\
\text { bakgrunnen hjå } \\
\text { førelesarane }\end{array}$ \\
\hline Oslo Met & $\begin{array}{l}\text { Kallar RLE-mod- } \\
\text { ulen "Det } \\
\text { mangfoldige } \\
\text { klasserommet" } \\
\text { Syklus 1: } 10 p \\
\text { Syklus 2: } 5 p\end{array}$ & $\begin{array}{l}\text { Ikkje presisert i } \\
\text { studie eller emne- } \\
\text { plan }\end{array}$ & $\begin{array}{l}\text { Ikkje presisert i } \\
\text { emneplanane }\end{array}$ & $\begin{array}{l}\text { Ikkje fastlagt } \\
\text { eller publisert }\end{array}$ & $\begin{array}{l}\text { Fagfordeling: } \\
\text { 6p Ped } \\
6 p \text { RLE } \\
\text { 3p samfunnsfag }\end{array}$ \\
\hline $\begin{array}{l}\text { Nord-Universi- } \\
\text { tetet }\end{array}$ & $\begin{array}{l}\text { Syklus } 1: 5 p \\
\text { Syklus 2: } 10 p\end{array}$ & $\begin{array}{l}\text { Syklus 1: Eitt arbe- } \\
\text { idskrav } \\
\text { Syklus 2: Eitt arbe- } \\
\text { idskrav }\end{array}$ & $\begin{array}{l}\text { Heimeeksamen } \\
\text { i RLE }\end{array}$ & $\begin{array}{l}\text { Syklus 1: 500s } \\
\text { Syklus 2: } \\
1000 \mathrm{~s}\end{array}$ & $\begin{array}{l}\text { Berre fagfolk frå RLE- } \\
\text { sek-sjonen }\end{array}$ \\
\hline $\begin{array}{l}\text { Universitetet i } \\
\text { Sørøst-Norge }\end{array}$ & $\begin{array}{l}\text { Ikkje presisert } \\
\text { i emneplanen. } \\
\text { Dei opplyser at det } \\
\text { skal være oml. } 15 \text { p } \\
\text { integrert i PEL }\end{array}$ & $\begin{array}{l}\text { Ikkje presisert i } \\
\text { studie eller emne- } \\
\text { plan }\end{array}$ & $\begin{array}{l}\text { Ikkje presisert i } \\
\text { emneplanane }\end{array}$ & $\begin{array}{l}\text { Ikkje fastlagt } \\
\text { eller publisert }\end{array}$ & Ikkje presisert på nett \\
\hline $\begin{array}{l}\text { Høgskulen i } \\
\text { Volda }\end{array}$ & $\begin{array}{l}\text { PEL } 1: 2 p \\
\text { PEL 3: } 4 p \\
\text { PEL 4: } 4 p \\
\text { PEL 5: } 5 p\end{array}$ & $\begin{array}{l}\text { PEL 2: Eit munnleg, indi- } \\
\text { viduelt arbeid knytt til } \\
\text { det tverrfaglege temaet } \\
\text { "Den fleirkulturelle, } \\
\text { livsynsmanfaldige og } \\
\text { fleirreligiøse skulen" }\end{array}$ & $\begin{array}{l}\text { Ikkje presisert i } \\
\text { emneplanane. } \\
\text { Dei opplyser at inn- } \\
\text { haldet frå modulen } \\
\text { inngår som eitt tema } \\
\text { i den individuelle, } \\
\text { skriftlege eksamenen } \\
\text { (PEL2) og som tema } \\
\text { i ein individuell } \\
\text { munnleg eksamen. }\end{array}$ & $\begin{array}{l}\text { Syklus 1: ca, } \\
400 \text { s } \\
\text { Syklus 2: ikkje } \\
\text { publisert }\end{array}$ & $\begin{array}{l}\text { Ikkje presisert på } \\
\text { nett. } \\
\text { Dei opplyser at arbeid } \\
\text { med emneplanar, } \\
\text { pensum og undervisning } \\
\text { knytt til modulen, skjer } \\
\text { i eit samarbeid mellom } \\
\text { Institutt for livssyn og } \\
\text { kyrkjefag og Institutt for } \\
\text { pedagogikk }\end{array}$ \\
\hline $\begin{array}{l}\text { Høgskolen i } \\
\text { Østfold }\end{array}$ & $\begin{array}{l}\text { Syklus 1: } \\
\text { Ped101: 2p } \\
\text { PED102: } 4 p \\
\text { Syklus 2: } \\
\text { PED401: } 4 p \\
\text { PED402: } 55\end{array}$ & $\begin{array}{l}\text { PED102: Deltaking } \\
\text { på seminar om } \\
\text { profesjonsetikk } \\
\text { Syklus 1: Éi obliga- } \\
\text { torisk oppgåve i RLE }\end{array}$ & $\begin{array}{l}\text { PED101: Ikkje } \\
\text { presisert } \\
\text { PED102: Ikkje } \\
\text { presisert } \\
\text { PED401: profe- } \\
\text { sjonsetikk } \\
\text { PED101: Ikkje } \\
\text { presisert }\end{array}$ & $\begin{array}{l}\text { PED101: ca } 160 \mathrm{~s} . \\
\text { PED102 ca. } 110 \mathrm{~s} . \\
\text { PED401; ca. } 35 \mathrm{~s} . \\
\text { PED402: ca } 270 \mathrm{~s} \\
\text { Totalt ca. } 575 \mathrm{~s} .\end{array}$ & $\begin{array}{l}\text { Berre syklus } 1 \text { er } \\
\text { køyrt. Dei opplyser at } \\
\text { RLE-tilssette er inne med } \\
10 \% \text { av kursressursen=> } \\
\text { ca. } 1,5 \text { p av } 6 \text { p }\end{array}$ \\
\hline
\end{tabular}

\section{Matrise 2}

\section{B. Institusjonar utan formell modulisering}

Av i alt 12 utdanningsinstitusjonar er det altså heile sju (7) som ikkje har noko formell, dvs. emneplanfesta modulisering av RLE i PEL-faget på 15 studiepoeng (sjå matrise 1). Dette gjeld lærarutdanninga ved Universitetet i Tromsø, Universitetet i Stavanger, NTNU, Universitetet i Agder, Høgskulen på Vestlandet og NLA.

Felles for desse institusjonane er at dei i større eller mindre grad har teke med læringsutbyteformuleringane i RLE frå retningslinene, men har elles inga klar og formell presisering av vektinga desse måla skal ha innanfor syklus 1 og 2. Generelt 
kan ein seie at desse utelukkande har lagt vekt på integrering av emna i PEL-faget som dei styrande dokumenta legg på dei, medan moduliseringa er fråverande eller $\mathrm{i}$ beste fall diffus (sjå matrise 3 ).

Likevel ser vi òg i denne gruppa store innbyrdes skilnader. Nokre har kopiert alle læringsmåla i RLE-modulen og limt dei rett inn i PEL-planane på dei ulike syklusane. Dette gjeld lærarutdanninga ved Universitetet i Tromsø, Universitetet i Stavanger, Høgskulen på Vestlandet, Universitetet i Agder og NLA. Dette kan tyde på at arbeidet med RLE-delen i PEL-planane ikkje har vore gjenstand for ei heilskapleg og fagleg handsaming. Dette kan òg tyde på at fagpersonell med RLE-bakgrunn ikkje har vore delaktige i utforminga av disse elementa i fagplanen. Lærarutdanningane ved Høgskolen i Innlandet og NTNU har vald ut nokre av læringsmåla frå retningslinene og arbeidd disse inn i planen (sjå matrise 3).

Dei to sistnemnde institusjonane verkar å ha forsøkt sy RLE-mål saman med det overordna fokuset dei har bestemt for PEL-faget lokalt. Samtidig er sentrale element frå retningslinene utelatne. Spesielt har læringspunktet som omhandlar kunnskapen «skolen i lys av kristen tradisjon», ein tendens til å verte fjerna eller tona ned. Dette gjeld ikkje berre desse to institusjonane, men òg institusjonar under den første hovudgruppa, med mellom anna OsloMet. Det synest som om fleire av utdanningsinstitusjonane har ønskt å fjerne eller dempe dette læringsmålet og i staden rette fokuset på tema som omhandlar skule meir allment og ikkje-kristne religionar (sjå matrise 3). Dette inneber nødvendigvis ikkje at kristen tradisjon og kristendommens retningar eller konfesjonar i praksis er utelatne, men det vert opna opp for store variasjonar avhengig av den faglege profilen åt fagpersonalet og fagpolitiske preferansar.

Undersøkinga vår viser vidare at alle utdanningsinstitusjonane i denne gruppa, med unntak av NLA, ikkje har emneplanfesta arbeidskrav eller vurderingar der RLE eksplisitt skal inngå. Fleire av institusjonane forsikrar gjennom korrespondanse at RLE-tema vil inngå på eksamen. Vi har ingen grunn til å tvile på dette, men igjen ser vi at det å ta vare på RLE-modulen vil vere avhengig av uformelle tilhøve og dei grepa som dei fagleg ansvarlege tek til ei kvar tid. Praksisen kan lett verte endra ved byte av fagpersonell eller bruk av vikarar.

Når det gjeld innhaldet og omfanget i pensumlitteraturen i denne gruppa av utdanningsinstitusjonar, er det som vert lagt ut på Internett særs variabelt, til liks med det vi ser hjå hovudgruppe 1 . Det er heller ikkje her mogleg å vurdere det relative omfanget av pensum til dei som har lagt ut pensumet på Internett, all den tid talet på studiepoeng i RLE på dei enkelte syklusane eller åra ikkje er avklart. 
Matrise 3: Institusjonar utan formell modulisering

\begin{tabular}{|c|c|c|c|c|c|}
\hline Institusjonar & $\begin{array}{l}\text { Integrering av } \\
\text { læringutbyte- } \\
\text { formuleringar } \\
\text { (LUB-ar) }\end{array}$ & $\begin{array}{l}\text { Arbeidskrav der } \\
\text { RLE eksplisitt } \\
\text { inngår }\end{array}$ & $\begin{array}{l}\text { Vurderings- } \\
\text { former i } \\
\text { RLE-modulen }\end{array}$ & Pensum i RLE & $\begin{array}{l}\text { Den faglege bakgrunnen } \\
\text { hjå førelesarane }\end{array}$ \\
\hline $\begin{array}{l}\text { Universitetet i } \\
\text { Tromsø }\end{array}$ & $\begin{array}{l}\text { Alle LUBA-ar er kop- } \\
\text { ierte og fordelte på } \\
\text { PEL i syklus } 1 \text { og } 2\end{array}$ & $\begin{array}{l}\text { Ikkje presisert i } \\
\text { emneplanane }\end{array}$ & $\begin{array}{l}\text { Etikkdelen i RLE } \\
\text { er teken vare } \\
\text { på i } 2 \text { veker i } 1 . \\
\text { studieår. } \\
\text { Tema religion, } \\
\text { livssyn, kris- } \\
\text { tendommens } \\
\text { treadisjon o.l. er } \\
\text { ikkje behandla. }\end{array}$ & $\begin{array}{l}\text { Syklus 1: } \\
\text { LER-1002: } \\
100 \text { s. Etikk } \\
170 \text { s. Livssyn frå } \\
\text { hausten } 2019 . \\
\text { LER-1003: Ikkje } \\
\text { noko RLE-spesi- } \\
\text { fikt pensum } \\
\text { Syklus 2: Ikkje } \\
\text { klarert. }\end{array}$ & $\begin{array}{l}\text { Men unntak av ei veke } \\
\text { våren } 2018 \text {, berre fagfolk } \\
\text { med pedagogikkfagleg } \\
\text { bakgrunn. } \\
\text { Det blir vurdert om RLE } \\
\text { skal inn på syklus } 2 \text { det } \\
\text { 5. året. }\end{array}$ \\
\hline $\begin{array}{l}\text { Høgskolen i } \\
\text { Innlandet }\end{array}$ & $\begin{array}{l}\text { Nokre av LUBa-ane } \\
\text { i RLE er tekne innog } \\
\text { omarbeidde. }\end{array}$ & $\begin{array}{l}\text { Ikkje presisert i } \\
\text { emneplanane }\end{array}$ & $\begin{array}{l}\text { Ikkje presisert i } \\
\text { emneplanane }\end{array}$ & $\begin{array}{l}\text { Syklus 1: ca.150 s } \\
\text { Syklus 2: Ingen }\end{array}$ & $\begin{array}{l}\text { Nøyaktig ressursfordeling } \\
\text { ikkje formelt fastsett. } \\
\text { Dei opplyser at fagfolk } \\
\text { med RLE-fagleg bakgrunn } \\
\text { skal inn i dei aktuelle } \\
\text { tema. }\end{array}$ \\
\hline $\begin{array}{l}\text { Universitetet i } \\
\text { Stavanger }\end{array}$ & $\begin{array}{l}\text { Alle LUBA-ar er } \\
\text { kopierte og fordelte } \\
\text { på PEL i syklus } 1 \\
\text { og } 2 \text { - } \\
\text { (Syklus } 1 \text { med PEL } 2 \\
\text { ca. } 5 \mathrm{p} .\end{array}$ & $\begin{array}{l}\text { Ikkje presisert i } \\
\text { emneplanane. } \\
\text { Dei opplyser at } \\
\text { RLE skal ha } 1 \\
\text { av } 4 \\
\text { arbeidskrav. }\end{array}$ & $\begin{array}{l}\text { Ikkje presisert i } \\
\text { emneplanane. } \\
\text { Dei opplyser at } \\
1 / 3 \text { av studentane } \\
\text { blir eksaminerte i } \\
\text { RLE-tema }\end{array}$ & $\begin{array}{l}\text { PEL 2: } 560 \mathrm{~s} . \\
\text { PEL 3: } 170 \mathrm{~s} . \\
\text { Totalt: } 770 \mathrm{~s} .\end{array}$ & $\begin{array}{l}\text { Nøyaktig ressursfordeling } \\
\text { ikkje formelt fastsett. } \\
\text { Dei opplyser at det er } \\
\text { fagfolk med RLE-fagleg } \\
\text { bakgrunn i dei aktuelle } \\
\text { tema. }\end{array}$ \\
\hline NTNU & $\begin{array}{l}\text { Enkelte av LUBA- } \\
\text { ane er omformul- } \\
\text { erte og temaet } \\
\text { "kristen tradisjon" } \\
\text { er fjerna heilt. }\end{array}$ & $\begin{array}{l}\text { Ikkje presisert i } \\
\text { emneplanane }\end{array}$ & $\begin{array}{l}\text { Ikkje presisert i } \\
\text { emneplanane }\end{array}$ & Ikkje presisert & $\begin{array}{l}\text { Nøyaktig ressursfordeling } \\
\text { ikkje formelt fastsett. } \\
\text { Dei opplyser at fagfolk } \\
\text { med RLE-fagleg bakgrunn } \\
\text { skal inn i dei aktuelle } \\
\text { tema }\end{array}$ \\
\hline $\begin{array}{l}\text { Høgskulen på } \\
\text { Vestlandet }\end{array}$ & $\begin{array}{l}\text { Alle LUBA-ane er } \\
\text { kopierte og fordelte } \\
\text { på PEL i syklus } 1 \text { og } \\
\text { 2. Dei opplyser at } \\
\text { det er eit tett ikkje- } \\
\text { formelt samarbeid } \\
\text { der RLE utgjer } 7,5+ \\
7,5 \text { i i PED } 2 \text { og } 4 \text {. }\end{array}$ & $\begin{array}{l}\text { Ikkje presisert i } \\
\text { emneplanane }\end{array}$ & $\begin{array}{l}\text { Ikkje presisert i } \\
\text { emneplanane }\end{array}$ & $\begin{array}{l}\text { Totalt syklus } 1 . \\
\text { ca. } 620 \mathrm{~s} \text {. } \\
\text { Totalt syklus 2: } \\
\text { Ikkje ferdigstilt }\end{array}$ & $\begin{array}{l}\text { Nøyaktig ressursfordeling } \\
\text { ikkje formelt fastsett. } \\
\text { Dei opplyser at fagfolk } \\
\text { med RLE-fagleg bakgrunn } \\
\text { skal inn i dei aktuelle } \\
\text { tema }\end{array}$ \\
\hline $\begin{array}{l}\text { Høgskolen i } \\
\text { Agder }\end{array}$ & $\begin{array}{l}\text { Alle LUBA-ane er } \\
\text { kopierte med små } \\
\text { endringar og for- } \\
\text { delta på PEL-emnet } \\
\text { i syklus } 1 \text { og } 2 .\end{array}$ & $\begin{array}{l}\text { Ikkje presisert i } \\
\text { emneplanane }\end{array}$ & $\begin{array}{l}\text { Ikkje presisert i } \\
\text { emneplanane }\end{array}$ & Ikkje presisert & $\begin{array}{l}\text { Dei opplyser at det er eit } \\
\text { uformelt samarbeid som } \\
\text { er slik: } \\
\text { Syklus } 1: 7,5 p \\
\text { Syklus } 2: 7,5 p \text { (under } \\
\text { planlegging) }\end{array}$ \\
\hline NLA & $\begin{array}{l}\text { Alle LUBA-ane er } \\
\text { kopierte og fordelte } \\
\text { på Pel-emnet i } \\
\text { syklus } 1 \text { og } 2 \text {. }\end{array}$ & $\begin{array}{l}\text { Ikkje presisert i } \\
\text { emneplanane. } \\
\text { Dei opplyser } \\
\text { at dette skjer i } \\
\text { samarbeid med } \\
\text { fagfolk med } \\
\text { RLE-bakgrunn. }\end{array}$ & $\begin{array}{l}\text { Emneplanfesta } \\
\text { tverrfagleg } \\
\text { heimeeksamen i } \\
\text { samarbeid med } \\
\text { fagfolk med } \\
\text { RLE-bakgrunn. }\end{array}$ & $\begin{array}{l}\text { Syklus 1: ca } 300 \text { s. } \\
\text { Syklus 2: Ikkje } \\
\text { fastlagt }\end{array}$ & $\begin{array}{l}\text { Det er fagfolk med } \\
\text { RLE-fagleg bakgrgunn i } \\
\text { dei aktuelle tema tilsva- } \\
\text { rande } 7,5 \mathrm{p} \text {. }\end{array}$ \\
\hline
\end{tabular}

\section{Matrise 3}


Nokre hovudkonklusjonar:

- Berre 5 av 12 lærarutdanningsinstitusjonar har formelt integrert 15 studiepoeng med RLE i PEL.

- Av desse 5 er det berre 3 institusjonar som har obligatoriske arbeidskrav der RLE-tema skal inngå.

- Av disse 5 er det berre 2 institusjonar som har definerte vurderingsformer der RLE skal inngå.

For institusjonar utan formell modulisering gjeld det òg:

- Manglande modulering gjer RLE-tema langt meir utydelege både med omsyn til arbeidskrav og vurdering.

- Det relative omfanget av pensum er til dels umogleg å vurdere i og med at talet på studiepoeng ikkje er fastlagt innanfor dei to syklusane.

For å kunne drøfte og vurdere desse funna, vil vi trekkje inn to eksterne prosessar: for den første den politiske prosessen kring opprettinga av modulen og for det andre dei diskusjonane som dette førte til i dei faglege miljøa.

\section{Dei politiske intensjonane med RLE-Emna}

\section{LARARUTDANNINGA}

Vi ser at fleire institusjonar ikkje nyttar formuleringane frå læringsutbyteformuleringane i retningslinene, og at ordet modul får ei særs laus organisatorisk tyding. Når det viser seg at tolkingane av lovteksten og retningslinene i emneplanane lokalt spriker som det gjer her, er det naturleg å sjå på forarbeida og den politiske presentasjonen av lova. Vi vil difor først presentere dette og det vi oppfattar som rimelege tolkingar av det. Dette vil òg kunne gje bakgrunn for å forstå kvifor rammeplanane og retningslinene er formulerte som dei er.

Den offentlege norske skulen har ei lang historie knytt til religionsundervisning, og for å få grep om dei politiske intensjonane ved RLE-modulen, må vi litt tilbake i tid. Skulen vart som kjend opphavleg skipa som ein del av verksemda åt statsreligionen, den lutherske og pietistiske kristendomsvarianten innført $\mathrm{i}$ kongeriket Danmark-Noreg på 1500-talet. Dei pietistiske aspekta ved skulen vart gradvis minska, og sekulære kunnskapsemne tok over. På ein måte kan ein seie at den norske skulen og lærarutdanningane som følgde med denne, er eit langt døme på sekulariseringssoga. Først i 1969, og så meir endeleg i og med innføringa av læreplanen i 1997, fekk vi eit meir gjennomført brot mellom statskyrkja og religionsfaget i skulen. No kom både allmenn filosofi og etikk, sekulære livssyn og ei rad religiøse retningar og religionar inn som undervisningstema i tillegg til kristendomskunnskap.

I den nasjonale lærarutdanningsmodellen frå 1998 var det nye emnet, KRL, 
òg obligatorisk i allmennlærarutdanninga for undervisning på alle trinna 1-10. Seinare i 2003 vart kurset minska frå 30 til 20 poeng, men framleis var det obligatorisk for alle studentane. I 2010 vart religionsfaget gjort valfritt (jf. KD 2010). I perioden frå 2010 til 2017 var det berre eit fåtal av lærarstudentane som fekk kompetanse i skulefaget. Både fagfolk og politikarar stilte raskt spørsmål om kor lurt dette var i lys av dei meir generelle utfordringane samfunnet stod overfor i eit fleirkulturelt samfunn som i stor grad også var fleir-religiøst (jf. statsråd Røe Isaksens tale til Stortinget sitert nedanfor; sjå Fuglseth 2010; Fuglseth og Schanke 2014).

Den nye borgarlege regjeringskoalisjonen (Solberg-regjeringa) frå 2013 byrja planlegginga av ei femårig lærarutdanning der religion, livssyn og etikk igjen skulle vere obligatoriske kunnskapstema, og reforma med denne grunnskulelærarutdanninga kom opp som sak i Stortinget i 2016. Forslaget til vedtak var eit resultat av ei forhandling med støttepartia åt Regjeringa i Stortinget. Det er difor vanskeleg å vite kva representantane for dei ulike partia i fleirtalet eigentleg meinte om forslaget. Det vi veit, er det statsråden sa, og i eit innlegg på Stortinget 2. juni 2016 grunngjev Torbjørn Røe Isaksen (2016) forslaget. Dette innlegget er då òg stortingsfleirtalet sin offisielle intensjon med forslaget, og er det som kan gje føringar på tolkinga av rammeplanen. Om RLE i den nye utdanninga sa statsråden at det var to grunnar til at regjeringa ønskte seg ei ny ordning, nemleg den fleirkulturelle situasjonen i norske klasserom og PEL-fagets relativt opne karakter:

Helt til slutt vil jeg si to ord om RLE. Dette er selvfolgelig unødvendig å gjenta $i$ denne sal, som er fullt klar over det, men det er selvfolgelig ikke slik at RLE, som vi snakker om i forbindelse med PEL-faget, har noe direkte med faget KRLE, eller det gamle faget, å gjore. Det vi snakker om, er RLE-relevant kompetanse, som i dag allerede er til stede i PEL-faget, men som vi ønsker å synliggjore tydeligere i en ny modul.

Det har to viktige ärsaker. For det forste vet vi at klasserom nesten uansett hvor man er $i$ Norge $i$ dag, blir mer varierte, og at problemstillinger med utgangspunkt i nettopp etikk, livssyn, forskjellig tro og forskjellige kulturer blir mer relevante. Da er det viktig at vi legger et ekstra trykk på det. For det andre er det også slik at selv om PEL-faget $i$ stor grad er et pedagogikffag, har Stortinget ved alle korsveier sagt at det ikke er slik at pedagogikkmiljøene «eier» PEL-faget alene. Vi ønsker at både PEL-fag og de andre fagene skal trekke på et bredt spekter av fagmiljoer. Det betyr også at f.eks. når RLE-relaterte kompetansemål blir synliggjort, kan det åpne for f.eks. et fruktbart samarbeid mellom pedagogikkmiljøer og RLE-miljøer på de forskjellige universitetene og høyskolene.

Begge desse grunnane er viktige for drøftinga vår av implementeringa av RLE-modulen. For det første dreier det seg om ei tydelegare synleggjering av 
REL-temaa enn det som låg i den førre modellen (jf. KD 2010). Han gjev ikkje ei vurdering av om implementeringa av desse RLE-emna i PEL-faget frå 2010 var vellukka, men kan vel seiast å indirekte uttrykkje ei viss misnøye med dette i og med ønsket om å synleggjere desse emna tydelegare i den nye planen. For det andre strekar han òg under at PEL-faget ikkje berre skal vere eit pedagogikkfag, og at pedagogikkmiljøa ved utdanningane må samarbeide med andre om faget, inkludert RLE-miljøa ved desse institusjonane. Forståinga hans av faget pedagogikk er kanskje noko smal, men som han sjølv òg seier, utdanningsinstitusjonane kan på sjølvstendig grunnlag vurdere kven som er best eigna til å undervise i RLE-kunnskapsemna.

Eit poeng i denne samanhengen som han ikkje kommenterer, er at undervisninga skal vere forskingsbasert, noko som òg legg føringar på kven som skal undervise. Omgrepet «forskingsbasert undervisning» vert definert på ulike måtar i faglitteraturen. Vågan og Kyvik (2014 s. 124) gjev heile åtte ulike definisjonar av det. Éin av dei handlar om undervisarens eigen bakgrunn i forsking på undervisningstemaet, og ein annan om at innhaldet $\mathrm{i}$ undervisninga skal vere tufta på forsking. Forsvarleg undervisning krev at desse to punkta heng saman til ein viss grad. Slik vi ser det, må den ansvarlege for den konkrete undervisninga, dvs. dei som møter studentane, som stør dei under studiet og vurderer kompetansen deira, såleis ha noko formell forskingskompetanse i kunnskapsområde eller som eit minimumskriterium ha studert disiplinar som forskar i desse områda. Både filosofi, religionsvitskap og teologi er døme på basisfag som gjer det.

Fleirtalet på Stortinget bestemte då at det $\mathrm{i}$ denne utdanninga skal vere obligatoriske RLE-tema for alle studentane. Vi fekk så den omtalte forskrifta om rammeplanen for både GLU for trinn 1-7 og 5-10 og retningslinene frå UHR som seier at det skal vere ein $R L E$-modul tilsvarande 15 studiepoeng integrert $\mathrm{i}$ PEL-faget i grunnskulelærarutdanninga (jf. ovanfor).

Men i rundskrivet frå departementet om forskrifter om rammeplanen for utdanninga (sjå KD 2016c med merknad til par. 3 i forskrifta) vart dette forklart på denne litt overraskande måten:

Pedagogikk og elevkunnskapsfaget er et profesjonsrettet loererutdanningsfag. I faget inngår kunnskap om religion, livssyn og etikk tilsvarende 15 studiepoeng. Eksempler på kunnskapsemner er samarbeid mellom skole og hjem, klassemiljo og klasseledelse $i$ et flerkulturelt og flerreligiest samfunn og profesjonsetikk. Kunnskapsemnene er integrert i PEL-faget og gir ikke grunnlag for å undervise i grunnskolens KRLE-fag, slik lererutdanningsfaget religion, livssyn og etikk gjor.

Her brukar departementet ikkje ordet modul, og ein kan lure på kvifor. Det kan $i$ alle fall ikkje verte oppfatta som ei oppheving av forskrifta. Poenget er vel berre igjen å seie at denne delen av PEL-faget ikkje gjev kompetanse til undervisning $\mathrm{i}$ 
KRLE-faget, slik statsråden òg peika på i sitt innlegg på Stortinget. Om nokon av institusjonane berre skulle ta omsyn til dette rundskrivet, oppfattar vi det som ei feiltolking av det. Rundskrivet gjev ikkje stø til ei tolking av forskrifta som ser bort frå formuleringa om ein modul. Det er den allmenne lærarkompetansen i det fleirkulturelle og fleirreligiøse samfunnet som er poenget både $i$ innlegget åt statsråden i Stortinget og i rundskrivet som vart send ut som rettleiing til forskrifta.

Avvik frå retningslinene vil mot denne bakgrunnen stå fram som noko som undergrev dei politiske intensjonane og vedtaka om modulen, med mindre ein i dei lokale emneplanane kan finne andre formuleringar som betre dekkjer intensjonen. Materialet vårt viser altså at sju av tolv institusjonar ikkje formelt har modulisert 15 studiepoeng. Såleis har dei ikkje gjort greie for kvar desse 15 studiepoenga skal inn i studiet. I stor grad har dei heller ikkje lagt fram kvar i PEL-faget arbeidskrav og vurdering i RLE-emna skal inngå. Avviket frå politiske intensjonar, forskrift og retningslinene er i desse tilfella tydeleg.

\section{DisKuSJONEN PÅ LÆRARUTDANNINGANE}

Den nye RLE-modulen i PEL-faget skapte ein del motstand blant fagfolk i på lærarutdanningane, og det er mogleg å tolke manglane i implementeringa i lys av dette. Mange av dei som underviste i det tidlegare pedagogikk- og pel-faget, kjente med rette på at dei mista ein stor del av eit allereie pressa profesjonsfag $\mathrm{i}$ lærarutdanninga, noko som kom til uttrykk i fleire avisinnlegg (jf. Steinsvik og Thorsen 2019). Dette er ofte fagfolk med lang praktisk erfaring i læraryrket og som veit noko om alt det ei utdanning til det må ta høgde for. Sentrale profesjonsfaglege instansar gjekk òg mot etableringa av modulen med ei slik grunngjeving. Utdanningsforbundet gjekk sterkt ut mot modulforslaget i høyringsfråsegna si. ${ }^{5}$ Fagfolk med bakgrunn i undervisninga av RLE-faget tok på si side godt imot den nye modulen, slik Skrefsrud $(2018$; 2019) seier det når han argumenterer både generelt og praktisk for at denne RLE-kunnskapen er ein del av lærarens allmenne profesjonskunnskap. Utan å ville etablere enkle stereotypar, kan vi seie at det var ein tendens til at dei som var for modulen på denne tida, kunne vere fagpersonar med RLE-bakgrunn, medan dei som var mot, kunne vere fagpersonar som underviste i PEL og hadde fagpedagogisk bakgrunn. Innføringa vart i alle fall kontroversiell, både når det gjaldt vurderinga av kor nødvendig det var med ein eigen modul i RLE og seinare, med omsyn til utvalet av tema.

Kontroversen heldt fram etter vedtaket i Stortinget og kom tydeleg til uttrykk

5 «... pedagogikkfaget må styrkes, det må utgjøre minimum 60 studiepoeng av studiet og en egen RLE-modul på 15 studiepoeng må ikke innlemmes i faget» (Utdanningsforbundet 2016a). Understrekinga av «ikke» med kursiv kjem ikkje fram i nettversjonen av fråsegna, men står i sjølve høyringsbrevet. Det er berre fem slike understrekingar i dette brevet, noko som indikerer at Utdanningsforbundet meinte alvor med innspelet. I forbundets nettsider (Utdanningsforbundet 2016b) står det òg at « $[\mathrm{u}]$ tdanningsforbundet fraråder på det sterkeste å innlemme en modul på 15 studiepoeng med RLE i pedagogikkfaget». 
då retningslinene skulle verte utforma. Departementet ville ikkje sjølv styre innhaldet i kvart undervisningsfag i den nye utdanninga og overlét til UHR Lærarutdanning å utforme retningslinene for kvart fag og emne. Desse retningslinene er i motsetnad til rammeplanen ikkje juridisk forpliktande på den same måten, men dei skal vere ei vidare konkretisering av forskrifta ved mellom anna å føreslå læringsutbyteformuleringar. Dette er eit poeng som er viktig for å forstå det som har skjedd med innføringa av RLE-modulen lokalt. Ordninga med å overlate innhaldet til UHR er innført som ei fast ordning, så departementet overfører i praksis denne styringa til fagpersonar oppnemnde av UHR. Overføringa er logisk nok. Ein unngår mange og lange prosessar i departementet om detaljar som følgjer med formelle høyringsrundar. Innhaldet kan no bestemmast med meir uformelle høyringar mellom fagfolka med bakgrunn i utdanningane og i grunnskulen i ein kontinuerleg prosess. Men samstundes førte, og fører, dette naturleg nok til mange og lange dragkampar innanfor faggruppene i UHR Lærarutdanning.

Kvart undervisningsfag i den nye GLU-en fekk ei faggruppe i UHR som skulle formulere retningslinene. ${ }^{6} \mathrm{I}$ faggruppa for PEL var det naturleg nok òg med representantar frå faggruppa i KRLE. ${ }^{7}$ Denne utvida PEL-gruppa vart ikkje samde om innhaldet i retningslinene, noko som dokumenterast i alle dei ulike forslaga som kom inn. Vi kan ikkje gå inn på alle detaljane i denne diskusjonen her, det er unødvendig i denne samanhengen. Vi konstaterer berre at styringsgruppa for arbeidet med retningslinene i UHR presentere eit nytt felles forslag, det som er noverande nasjonale retningsliner. Men på bakgrunn av den store usemja om RLE-emna, først i samband med høyringane og den politiske handsaminga og så i UHR-faggruppa for PEL, er det grunn til å tru at diskusjonane om modulen har halde fram ved kvar einskild utdanningsinstitusjon med GLU. Dette gjev ei forklaring på dei mange ulike emneplanutformingane vi har funne. Usemja kan òg forklare kvifor dei lokale prosessane har teke lang tid, slik at planane på mange institusjonar ikkje var på plass før utdanninga skulle starte opp med sitt første kull i 2017, noko NOKUT hadde kravd i sine akkrediteringsvilkår.

\section{KONKLUSJONAR: AVVIK OG IGNORERING}

Det vi ønskte å finne ut av i denne studien, var korleis institusjonane har implementert forskrifta om RLE-modulen i PEL-faget i den nye grunnskulelærarutdanninga. Forskrifta, retningslinene og dei politiske intensjonane om dei obligatoriske RLE-temaa i lærarutdanninga gjeld for alle lokale studie- og emneplanar: Emna skulle organiserast $i$ ein eigen modul i det generelle profe-

6 Gruppene var: 1) Pedagogikk- og elevkunnskap PEL, 2) Norsk, 3) Matematikk 4) Engelsk 5) Andre framandspråk, 6) Kroppsøving, 7) Kunst- og handverk, 8) Mat og helse, 9) Musikk, 10) Naturfag, 11) RLE (KRLE), 12) Samfunnsfag og historie.

7 Gruppa i KRLE vart leia av Kåre Fuglseth. Utsendingane frå KRLE-gruppa til PEL-gruppa var Helje K. Sødal (frå UiA) og Ådne Valen-Senstad (frå HBV, no USN). 
sjonsfaget Pedagogikk og elevkunnskap (PEL), men likevel vere integrerte i dette profesjonsfaget.

Vi har funne at stort sett alle institusjonane følgjer forskrift og retningsliner når det gjeld integrasjon av modulen i PEL-faget. Vi tenkjer då på at mange av læringsutbyteformuleringane trass alt er tydelege i dei lokale planane. Men vi fann òg at dei fleste ignorerer forskrifta når det gjeld krav til modulisering. Berre fem av tolv institusjonar hadde ein emneplanfesta RLE-modul der det kjem fram korleis studiepoenga skal fordelast. Blant desse fem er det store variasjonar med omsyn til fagplanfesta arbeidskrav og vurderingsformer der RLE skal vere med. Hjå dei som ikkje har formell modulisering, finn vi òg store skilnader. Nokre har klipt og limt frå retningslinene utan vidare i emneplanane sine, andre har vald å ignorere temapunkt, særleg punktet om å ha kunnskap om skulen i lys av kristen tradisjon. Ignoreringa og fjerninga av kristendomen si rolle i skule og samfunn før og no, er eit markant avvik. Parameter som læringsutbyteformuleringar, arbeidskrav og pensumlitteratur knytte til RLE er ofte ikkje spesifiserte. På denne bakgrunnen er det klart at lærarstudentar kan stå i fare for ikkje å få den utdanninga som forskrifta legg opp til. I så fall vil dei i utdanninga si ikkje få høve til å reflektere over grunnleggande spørsmål om religion, livssyn og etikk som i det fleirkulturelle samfunnet er vortne så nødvendige å ha innsikt $\mathrm{i}$.

Frå nokre uformelle kjelder $\mathrm{i}$ materialet vårt går det fram at sjølv om ein modul på 15 studiepoeng ikkje er emneplanfesta lokalt, så er han likevel teken vare på gjennom pensum, arbeidskrav og vurderingsformer, og såleis i praksis noko studentane vil møte. Vi tviler ikkje på dette. Likevel meiner vi at manglande emneplanfesting gjer at undervisninga vert for personavhengig, lett kan variere frå år til år, og noko som endrar seg med personalskifte, vikarbruk o.l.

Slik vi ser det, har striden om RLE-modulen vore ein avgjerande faktor for denne stoda. Det store spriket mellom lærarutdanningane i emneplanane kan òg verte forklart med at forskrifta, rundskrivet og retningslinene har opna opp for denne situasjonen ved å vere for upresise eller for lite konkrete når det gjeld organisering. Ei endring i forskrifta eller eit nytt rundskriv som tydeleg seier kva departementet meiner med «ein integrert modul» på 15 studiepoeng vil kunne endre på dette.

\section{LitTERATUR}

Afdal, H. \& F. Bjordal. 2019. 5-årig grunnskolelærerutdanning på masternivå. Ny og utfordrende. Et følgeforskningsprosjekt ved Høgskolen i Østfold. Delrapport 1. Horten: Høgskolen i Østfold.

Fosse, B. og S. Hovdenak. 2014. «Lærerutdanning og lærerprofesjonalitet i spenningsfeltet mellom ulike kunnskapsformer». Norsk pedagogisk tidsskrift (2): 66-79. 
Fuglseth, K. 2010. «Exit religion? Om RLE-faget i den nye grunnskulelærarutdanninga.» Kirke og kultur 115(3): 192-200.

Fuglseth, K. \& Schanke, Å. 2014. «RLE-fag på vikende front». Kirke og Kultur, 119(4): 313-324.

Grunnskolelova. 1998. https://lovdata.no/dokument/NL/lov/1998-07-17-61/ KAPITTEL_1. Lasta 30. oktober 2019.

Isaksen, T. R. 2016. Tale til Stortinget. Referert og publisert av Stortinget, Sak nr. 8 [14:39:12] https://www.stortinget.no/no/Saker-og-publikasjoner/ Publikasjoner/Referater/Stortinget/2015-2016/160602/8. Lasta ned 30. oktober 2019.

Karlsen, S., M. Olufsen, O. Haugland \& S. Thorvaldsen. 2017. «Et tidlig gløtt inn i den nye norske lærerutdanningen. En komparativ studie av allmennlærer- og masterutdanning i naturfag for grunnskolen». Uniped 40(4): 299-311.

KD. 2010. Kunnskapsdepartementet. Nasjonale retningslinjer for grunnskolelærerutdanningen 1.-7. trinn. https://www.regjeringen.no/globalassets/upload/kd/ rundskriv/2010/retningslinjer_grunnskolelaererutdanningen_1_7_trinn.pdf. Lasta ned 30. oktober 2019.

KD. 2016a. Kunnskapsdepartementet. Forskrift om rammeplan for grunnskolelærerutdanning for trinn 1-7 https://lovdata.no/dokument/SF/ forskrift/2016-06-07-860?q=forskrift\%20rammeplan\%20grunnskolelærer. Lasta ned 30. oktober 2019.

KD. 2016b. Kunnskapsdepartementet. Forskrift om rammeplan for grunnskolelærerutdanning for trinn $5-10 \mathrm{https} / / /$ lovdata.no/dokument/SF/ forskrift/2016-06-07-861?q=forskrift\%20rammeplan\%20grunnskolelærer. Lasta ned 30. oktober 2019.

KD. 2016c. Kunnskapsdepartementet. Rundskriv F-06-16. Rundskriv med merknader til forskrifter om rammeplaner for grunnskolelærerutdanningene (dagsett 8.7.2016, retta 2.1.17) https://www.regjeringen.no/ contentassets/c454dbe313c1438b9a965e84cec47364/rundskriv-medmerknader-til-forskrifter-om-rammeplaner-for-grunnskolelarerutdanningene_ rettet020117.pdf. Lasta ned 30. oktober 2019.

Mayring, P. 2015. "Qualitative Inhaltsanalyse.» I Qualitative Forschung. Ein Handbuch. U. Flick, E. von Kardorff og I. Steinke (red.). Hamburg: Rowolt, side 468-475.

NOKUT. 2016. Nasjonalt organ for kvalitet i utdanning. Veiledning til studietilsynsforskriften. Med retningslinjer for utforming av søknader om akkreditering av integrert femårig lærerutdanning på mastergradsnivå. For mastergradsstudier av 300 studiepoengs omfang. Offisielt dokument fra NOKUT, referanse 16/00406-20. Dagsett 08.07.2016. 
Schjetne, E. \& T.-A. Skrefsrud (red.) (2018). Å være lærer i en mangfoldig skole. Kulturelt og religiøst mangfold, profesjonsverdier og verdigrunnlag. Oslo: Gyldendal. Skagen, K. 2016. «Utdanningshistorie i ny lærerutdanning». Uniped 39(3): 271-285.

Skeie, G. 2018. «Religioner, livssyn og interkulturell opplæring.» I Å være lærer i en mangfoldig skole. Kulturelt og religiøst mangfold, profesjonsverdier og verdigrunnlag. E. Schjetne og T.-A. Skrefsrud. Oslo: Gyldendal, side 39-55.

Skrefsrud, T.-A. 2018. «Pedagogikk og elevkunnskap i en mangfoldig skole.» I A være lærer i en mangfoldig skole. Kulturelt og religiøst mangfold, profesjonsverdier og verdigrunnlag. E. Schjetne og T.-A. Skrefsrud. Oslo: Gyldendal, side 22-38.

Skrefsrud, T.-A. 2019. «Hvordan styrke den flerkulturelle lærerkompetansen? Religion, livssyn og etikk i PEL-faget.» Bedre skole (3): 48-51.

Steinsvik, B. og K. E. Thorsen. 2016. «Ny RLE-modul i lærermaster gir uklare roller.» I Khrono 8.4.16. Lasta ned 1.12.19. https://khrono.no/debatt/skaperuklare-roller-rundt-pedagogikken

UHR. 2017. https://www.uhr.no/temasider/nasjonale-retningslinjer-for-larerutdanningene/. Lasta ned 30. oktober 2019 (sist endra 2.10.2019).

UHR. 2018a. Nasjonale retningslinjer for grunnskolelærerutdanning, trinn 1-7. Sist revidert: 17.10 2018. vedtatt av UHR-Lærerutdanning 17.10.2018. https:// www.uhr.no/_f/p1/ibda59a76-750c-43f2-b95a-a7690820ccf4/revidert171018-nasjonale-retningslinjer-for-grunnskolelarerutdanning-trinn-1-7_fin. pdf._Lasta ned 30. oktober 2019.

UHR. 2018b. Nasjonale retningslinjer for grunnskolelærerutdanning, trinn 5-10. Sist revidert: 17.10 2018. Vedtatt av UHR-Lærerutdanning 17.10.2018. https:// www.uhr.no/_f/p1/iffeaf9b9-6786-45f5-8f31-e384b45195e4/revidert171018-nasjonale-retningslinjer-for-grunnskoleutdanning-trinn-5-10_fin.pdf. Lasta ned 30. oktober 2019.

Utdanningsforbundet. 2016a. Høringsuttalelse https://www.utdanningsforbundet. no/var-politikk/horingsuttalelser/2016/forskrifter-om-rammeplan-forfemarige-grunnskolelarerutdanninger---utdanningsforbundets-horingssvar/. Lasta ned 30. oktober 2019. Sjå https://www.utdanningsforbundet.no/ nyheter/2016/pedagogikk-ma-prioriteres/. Lasta ned 20. mars 2020.

Utdanningsforbundet. 2016b. Pedagogikk må prioriteres. Nettartikkel https://www. utdanningsforbundet.no/nyheter/2016/pedagogikk-ma-prioriteres/. Lasta ned 20. mars 2020.

Vågan, A. \& S. Kyvik (2014). Forskningsbasert utdanning? Forholdet mellom forskning, utdanning og yrkesutøvelse i de korte profesjonsutdanningene. Oslo: Abstrakt forlag. 